\section{Cross-border healthcare and prognosis of HIV infection in the triple border Brazil-Paraguay- Argentina}

\author{
A assistência à saúde transfronteira e o \\ prognóstico da infecção pelo HIV na tríplice \\ fronteira Brasil-Paraguai-Argentina
}

\author{
Atención sanitaria fronteriza y pronóstico de \\ infección por VIH en la triple frontera Brasil- \\ Paraguay-Argentina
}

Ricardo Zaslavsky 1,2 Barbara Niegia Garcia de Goulart 3 Patricia Klarmann Ziegelmann 3

doi: 10.1590/0102-311X00184918

\begin{abstract}
The act of crossing an international border for healthcare is a reality in border areas and the flow is in the direction of the city with more human and healthcare resources. Although several prognostic factors related to $\mathrm{HIV}+\mathrm{pa}$ tients are known, the prognostic value of this type of mobility for long term care is still neglected. This study compares the prognosis of HIV patients from three groups, one involved in regional mobility, another in cross-border mobility in search for healthcare and the reference group which is composed by patients living in the same city of the health facility. This is a retrospective cohort study using medical records from a healthcare service in Brazil. Following survival analysis with log-rank test and Cox proportional hazard models, overall survival had no significant difference between patients who were involved in regional $(H R=1.03 ; 95 \% C I$ : 0.69-1.54; $p=0.89)$ or international $(H R=1.07 ; 95 \%$ CI: 0.58-1.97; $p=0.83)$ mobility and those who were not. This lack of difference was kept when adjusted for known prognostic factors. In this retrospective cohort study, exposure to both regional and international migration did not have a significant association with the risk of death by any cause in crude or adjusted analyses for already known prognostic factors. This is the first study to consider the prognostic role of cross-border healthcare for HIV patients. Despite these findings, the need of monitoring the extent and the clinical and demographic characteristics of healthcare demand originated in the other side of the border and the use of these data for decision making in health management is emphasized.
\end{abstract}

HIV; Prognosis; Border Areas; Border Health

\author{
Correspondence \\ R. Zaslavsky \\ Secretaria Municipal de Saúde de Foz do Iguaçu. \\ Rua Tarquino Joslin dos Santos 1000, Foz do Iguaçu, PR \\ 85870-901, Brasil. \\ ricardo.zaslavsky@gmail.com \\ 1 Universidade Federal da Integração Latino-Americana, Foz do \\ Iguaçu, Brasil. \\ 2 Secretaria Municipal de Saúde de Foz do Iguaçu, Foz do \\ Iguaçu, Brasil. \\ 3 Programa de Pós-graduação em Epidemiologia, Universidade \\ Federal do Rio Grande do Sul, Porto Alegre, Brasil.
}




\section{Introduction}

Cross-border healthcare is a common practice worldwide $1,2,3$. Despite the scarcity of data, it is estimated that expenditures related to cross-border healthcare in the European Union (EU) are approximately EUR 10 billion a year ${ }^{4}$. Most of the research on cross-border patient mobility has studied the mobility from high income to low income countries, which is common in view of the lower healthcare costs 5,6. However, movement in the opposite direction also happens: from low and middle income countries to similar and high income countries. There are many reasons that lead patients to cross international borders from low or middle income to high income countries to seek healthcare. Some of them are the possibility of enhancing the chances of prolonging life in cases of severe diseases, the culture of looking for a better perceived care regardless of the location, escaping from medical professionals perceived as arrogant and mistrustful to look for more friendly and qualified physicians, easier access to reproductive medicine, greater ease of border crossing in comparison to going to the capital city of the country of residence, and gaining citizenship 7 . This international health-seeking behavior can lead patients to different types of mobility: permanent change of country of residence, characterizing immigration 8 ; longer but not permanent stay abroad for seasonal work, characterizing circular migration, which almost always demands healthcare 9,10 ; and daily mobility in which patients return to their homeland in the same day or within a few days, characterizing pendulum migration 11 .

Pendulum migration has been traditionally defined as the kind of mobility motivated by the search for work or study in a city which is not the one where the person lives 12 . The flow is mostly originated in small cities, which have fewer resources than the so-called functional regions. The latter are larger cities with more resources in terms of education and work 13 , usually capital cities 14,15 , and over a million people may travel per day in this flow. This type of mobility, however, can also occur from small to middle size cities 16 . Pendulum migration for healthcare appears in important Brazilian laws on public health, establishing for example the possibility of consortiums between many cities to collaborate with healthcare services ${ }^{17}$. In this context, larger cities can become "functional regions" in terms of health services in relation to smaller cities which can provide access to medical procedures that require more advanced technology.

In developing countries, this type of patient mobility for healthcare is common in border areas, with the flow of people in the direction of the city with more health resources, especially when social and economic disparities between countries are large as well as the consequent access and quality of the healthcare. Notwithstanding the foregoing, in these countries, the number of patients that cross the border seeking healthcare is poorly monitored 18,19 and its impact on health outcomes is still unknown. Pendulum migration for healthcare is the most common type of cross-border healthcare in the triple border Brazil-Paraguay-Argentina.

The triple border Brazil-Paraguay-Argentina is located along the encounter of Iguazu and Paraná rivers and includes the cities of Foz do Iguaçu (Brazil), Puerto Iguazu (Argentina) and Ciudad del Este (Paraguay). The estimated population of those cities is 263,915 20, 82,227 21 and 281,422 22, respectively. Therefore, this border area is one of the most populated of Latin America with a conurbation of approximately 627,564 citizens. The Brazilian city is also the regional health head office of the state of Paraná, which is composed additionally by eight other cities. Foz do Iguaçu is the triple border city with more healthcare resources. The number of Brazilians living in Paraguay (Braziguaian) is uncertain. According to the 2012 Paraguay census, there were 81,592 Brazilians living there 23 . However, according to the Brazilian Ministry of Foreign Affairs, the estimated number of Brazilian citizens living in Paraguay was 332,042 in 2016, with 200,000 living in the region of the Ciudad del Este consulate and, therefore, potential users of the Brazilian Unified National Health System (SUS) in Foz do Iguaçu 24. Nevertheless, the amount of patients (Braziguaian or Paraguaian) that periodically crosses the international border, usually from Paraguay to Brazil, to seek for healthcare is uncertain, as well as the impact of this human mobility on the healthcare of the population.

The prevalence of HIV infection on Brazilian and Paraguay border cities is higher than the Brazilian average 25,26 (Departamento de Informática do SUS. Casos identificados de AIDS no Brasil, município de residência: Foz do Iguaçu e Uruguaiana, http://www2.aids.gov.br/cgi/tabcgi.exe?tabnet/ br.def; População residente em Foz do Iguaçu e Uruguaiana, ano, http://tabnet.datasus.gov.br/cgi/tabcgi. exe?ibge/cnv/poppr.def, accessed on 24/Jan/2017) (Dirección General de Estadística y Censos. https:// 
www.dgeec.gov.py/ (accessed on 30/Mar/2018). Furthermore, the Brazilian health system offers universal access to antiretroviral therapy (ART) sponsored by the government. Although Paraguay has its own public health system, $65 \%$ of the population - who develop informal work activities - represent the main users of this system, which has no standard list of procedures to be offered 27 . This ultimately leads to restricted access for the poorer part of the population to healthcare, and the need to pay for private services. Considering this context, it is common for Brazilian and Paraguayan HIV patients living in Paraguay to cross the border to seek for healthcare in the Brazilian border city. Although prognostic factors for HIV infection are recognizably of socioeconomic 28,29,30,31, laboratorial 32,33,34 and clinical 35,36,37 nature, the effect of regional mobility or cross-border healthcare in the prognosis of HIV patients remains non-studied. Taylor et al. 38 suggest that HIV patients who cross international boundaries, adopting the pattern of pendulum migration for healthcare are less adherent to medications due to causes of individual (fear of experiencing side effects during the trip, changes in daily schedule, and the idea that the travel is a form of vacations in which they can take "vacations" from medication), social (fear of the stigma that leads the patient to hide the medication and forget to take it) and health (dispensing medications for only one month, and difficulty to travel more than once a month for healthcare) nature 38 . Such lack of adherence may potentially lead to poorer outcome. Moreover, living in a country and seeking healthcare in another brings many further potential difficulties to patients and services that might be related to a poorer outcome. These difficulties include the long distance traveled 39 ; living in rural areas with low access to transportation; insecurity about the right to use health system abroad (which makes patients hide their real origin and hinders the staff's efforts of measuring the extent of the health demand that originates from foreign countries) 40 ; problems faced by the staff when it is necessary to make contact with patients living in a foreign country; problems to get in contact with the social support network abroad when patients are involved in situations of violence or violation of human rights; slowness to cross the bridge that connects the two countries; fear of being searched in customs facility; and having the diagnosis discovered or being accused of carrying illegal drugs; the negotiations to receive medications are usually frustrated for more than a month; limited access to emergency rooms in the same facility where the patient receives ambulatory care; and uncomfortable eventual need of committing to vote in a specific politician or return political favors so as to have access to an easier transport for health service.

Despite these risks to which international migrants might be exposed, there are no evidences that regional or international mobility to seek for healthcare affects the survival of patients who need longitudinal care for chronic conditions such as HIV infection.

Therefore, the objective of this research is to compare the prognosis of HIV patients who live in the same city of the healthcare facility (Foz do Iguaçu) with patients that come from smaller neighboring cities in Brazil (regional mobility) and patients that cross the international border from Paraguay to seek healthcare (cross-border healthcare) in the Specialized Assistance Service (SAE) of Foz do Iguaçu.

\section{Methods}

This retrospective cohort study investigated all HIV patients registered in the SAE between January 1st, 2003, and August 31st, 2011. The initial date was established to ensure that patients using antiretroviral therapy were using highly active antiretroviral therapy (HAART), because the first Brazilian guideline that included only HAART regimen was the 2003 guideline. The final date was chosen to ensure that all patients had the chance to have a follow-up of at least five years, because data collection was completed on August 31st, 2016. Patient data were extracted from medical records (consultations, dispensing of medicines, and laboratory test registers) and were peer-reviewed. The inclusion criteria were: men and women age 16 years or older, living in Foz do Iguaçu or any other of the eight cities of this health department or in Paraguay, diagnosed with HIV positive and, if undergoing pharmacological treatment, using HAART. The exclusion criteria were: patients using mono or dual therapy at some point of the follow-up, patients who spent $>50 \%$ of the follow-up in other healthcare service, and those with no date registration of the outcome or the outcome itself. 
The outcome was death by any cause. The date considered was the one noted in the patient's medical records. For patients whose records had no information about this outcome, we used data from the Brazilian Information System for Notifiable Diseases (SINAN), Brazilian National Mortality Information System (SIM) and consulted the SAE staff for more information about patient status.

The main factor of exposure of interest was patient mobility with the pattern of pendulum migration, which was defined as the mobility from the city of residence to Foz do Iguaçu, without permanent change of residence, to receive care for HIV infection. Exposure was categorized in: regional mobility (patients living in Brazilian neighbouring cities of Foz do Iguaçu, part of the 9th regional health coordination of the state of Paraná, Brazil), cross-border mobility (patients living in Paraguay, both Braziguaian and Paraguaian) and no mobility (patients living in Foz do Iguaçu). The last group was considered the reference group. The adjustment factors considered were: initial CD4 lymphocyte count (cells $/ \mu \mathrm{L})$, initial viral load (copies $/ \mu \mathrm{L})$, initial hemoglobin $(\mathrm{mg} / \mathrm{dL})$, CD4 curve, use of HAART (yes or no), prophylaxis against opportunistic infections, initial age, family income and education $29,31,32,34,35,41,42$. All those factors were considered as categorical variables and those categorizations are shown in Table 1.

Table 1

Sociodemographic, clinical and laboratory characteristics of patients followed by Specialized Assistance Service (SAE) and registered between January 2003 and August, 2011.

\begin{tabular}{|c|c|c|c|c|c|}
\hline Variables & $\begin{array}{l}\text { No mobility } \\
\text { [n = 649] } \\
n(\%)\end{array}$ & $\begin{array}{c}\text { Regional mobility } \\
\text { [n = 116] } \\
n(\%)\end{array}$ & $\begin{array}{l}\text { Cross-border mobility } \\
\qquad\left[\begin{array}{c}n=48] \\
n(\%)\end{array}\right.\end{array}$ & $\begin{array}{c}\text { Total } \\
\text { [n = 813] } \\
n(\%)\end{array}$ & p-value \\
\hline Age (years) & & & & & 0.659 \\
\hline$<27$ & $141(21.73)$ & $27(23.28)$ & $16(33.33)$ & $184(22.63)$ & \\
\hline $27-34$ & $185(28.51)$ & $32(27.59)$ & $14(29.17)$ & $231(28.41)$ & \\
\hline $34.1-42$ & $167(25.73)$ & $29(25.00)$ & $10(20.83)$ & $206(25.34)$ & \\
\hline$>42$ & $156(24.04)$ & $28(24.14)$ & $8(16.67)$ & $192(23.62)$ & \\
\hline Sex & & & & & 0.028 \\
\hline Male & $327(50.39)$ & $47(40.52)$ & $30(62.50)$ & 404 (49.69) & \\
\hline Marital status & & & & & 0.024 \\
\hline Single & $191(29.43)$ & $35(30.17)$ & $17(35.42)$ & $243(29.89)$ & \\
\hline Married & $324(49.92)$ & $53(45.69)$ & $21(43.75)$ & $398(48.95)$ & \\
\hline Separated/Divorced & $94(14.48)$ & $12(10.34)$ & $8(16.67)$ & $114(14.02)$ & \\
\hline Widow & $30(4.62)$ & $16(13.79)$ & $2(4.17)$ & $47(5.78)$ & \\
\hline Educational level * & & & & & 0.025 \\
\hline Low & $357(55.01)$ & $68(58.62)$ & $18(37.50)$ & $443(54.49)$ & \\
\hline Intermediate & $137(21.11)$ & $23(19.83)$ & $8(16.67)$ & $168(20.66)$ & \\
\hline High & $141(21.73)$ & $21(18.10)$ & $19(39.58)$ & $181(22.26)$ & \\
\hline Family income ** & & & & & 0.005 \\
\hline$<2$ & $267(41.14)$ & 45 (38.79) & $15(31.25)$ & $327(40.22)$ & \\
\hline $2-5$ & $150(23.11)$ & $37(31.90)$ & $8(16.67)$ & 195 (23.99) & \\
\hline$>5$ & $45(6.93)$ & $6(5.17)$ & $9(18.75)$ & $60(7.38)$ & \\
\hline Initial CD4 (cells/ $\mu \mathrm{L})$ & & & & & 0.391 \\
\hline$<200$ & $160(24.65)$ & $33(28.450$ & $15(31.25)$ & $208(25.58)$ & \\
\hline $200-349$ & $140(21.57)$ & $20(17.24)$ & $6(12.50)$ & $166(20.42)$ & \\
\hline $350-499$ & $117(18.03)$ & $17(14.66)$ & $7(14.58)$ & $141(17.34)$ & \\
\hline$\geq 500$ & $179(27.58)$ & $41(35.34)$ & $13(27.08)$ & $233(28.66)$ & \\
\hline CD4 curve *** & & & & & 0.846 \\
\hline$<-25$ & $130(20.03)$ & $20(17.24)$ & $8(16.67)$ & $158(19.43)$ & \\
\hline-25 to +25 & 59 (9.09) & $10(8.62)$ & $4(8.33)$ & $73(8.98)$ & \\
\hline$>+25$ & $286(44.07)$ & 57 (49.14) & $24(50.00)$ & 367 (45.14) & \\
\hline
\end{tabular}

(continues) 
Table 1 (continued)

\begin{tabular}{|c|c|c|c|c|c|}
\hline Variables & $\begin{array}{c}\text { No mobility } \\
\text { [n = 649] } \\
n(\%)\end{array}$ & $\begin{array}{l}\text { Regional mobility } \\
\text { [n=116] } \\
n(\%)\end{array}$ & $\begin{array}{l}\text { Cross-border mobility } \\
\text { [n }=48] \\
n(\%)\end{array}$ & $\begin{array}{c}\text { Total } \\
\text { [n = 813] } \\
\text { n (\%) }\end{array}$ & p-value \\
\hline Initial viral load (cells $/ \mu \mathrm{L})$ & & & & & 0.369 \\
\hline$\leq 400$ & $73(11.25)$ & $15(12.93)$ & $10(20.83)$ & $98(12.05)$ & \\
\hline 401-9.999 & $196(30.20)$ & $37(31.90)$ & $9(18.75)$ & $242(29.77)$ & \\
\hline 10.000-99.999 & $193(29.74)$ & $33(28.45)$ & $11(22.92)$ & $237(29.15)$ & \\
\hline$\geq 100.000$ & $120(18.49)$ & $23(19.83)$ & $9(18.75)$ & $152(18.70)$ & \\
\hline Initial haemoglobin (mg/dL) & & & & & 0.326 \\
\hline$<8$ & $13(2.00)$ & $1(0.86)$ & $1(2.08)$ & $14(1.72)$ & \\
\hline 8-9.9 & $54(8.32)$ & $4(3.45)$ & $1(2.08)$ & $59(7.26)$ & \\
\hline $10-11.9$ & $140(21.57)$ & $31(26.72)$ & $9(18.75)$ & $180(22.14)$ & \\
\hline$\geq 12$ & $360(55.47)$ & $69(59.48)$ & $27(56.25)$ & 456 (56.09) & \\
\hline Use of HAART & & & & & 0.898 \\
\hline Yes & $541(83.36)$ & $96(82.76)$ & $37(77.08)$ & $674(82.90)$ & \\
\hline $\begin{array}{l}\text { Prophylaxis against opportunistic } \\
\text { infection }\end{array}$ & & & & & 0.350 \\
\hline Yes & $186(28.66)$ & $39(33.62)$ & $11(22.92)$ & $236(29.03)$ & \\
\hline
\end{tabular}

HAART: highly active antiretroviral theraphy.

* Low educational level: illiterate or incomplete elementary school; Intermediate educational level: complete elementary school or incomplete high school; High educational level: complete high school or complete or incomplete graduation;

** Family income was categorized with the classification used by the health service. The numbers in the category are the amount of minimal wages received monthly by the family;

*** Calculated by the subtraction of the first CD4 count by the second.

The Kaplan-Meier method was used to estimate overall survival. Time to death was measured in days from the date of the first appointment in the SAE until death from any cause. Survival curves were estimated for the three groups (regional mobility, international mobility, and no mobility) and compared by the log-rank test. Cox proportional hazards model was used to adjust survival curves for already known prognostic factors quoted previously. Adjustments were made using one factor at a time. Multivariable adjustments were not made because of the low number of deaths in the international mobility group. Patients who, in the date of extraction, had the last consultation six months before or more were considered abandonment of treatment according to the definitions of the Brazilian Ministry of Health 43. Patients who abandoned treatment or were transferred to another service were considered censored in the date of the last consultation. Those who did not die and continued receiving care on the SAE were considered administratively censored in the date of the last consultation. The significance level defined was $5 \%$ and data were analyzed with the SPSS 18.0 (https://www. ibm.com/). Patients and their families were not directly contacted because this was not part of the plan by the time of the ethical appreciation by the committee. The study was approved by the ethics research committee of Federal University of Rio Grande do Sul (UFRGS) under case review CAAE: 53201216.5.0000.5347.

\section{Results}

Inclusion criteria were met by 813 patients but five of them were not included in this study because the absence of date of registration or outcome. Among the patients, 644 (79.7\%) lived in Foz do Iguaçu, 116 (14.4\%) lived in cities of the health department, and 48 (5.9\%) lived in Paraguay. Demographic, clinical and laboratorial characteristics of patients are presented in Table 1.

Patients living in Paraguay were the youngest among the three groups by the time of the diagnosis and first consultation and had proportionally more male patients. This group had also the higher educational level, family income and patients with initial viral load $\leq 400 \mathrm{copies} / \mu \mathrm{L}$. On the other hand, the 


\section{Figure 1}

Overall survival time (in days) by mobility pattern.

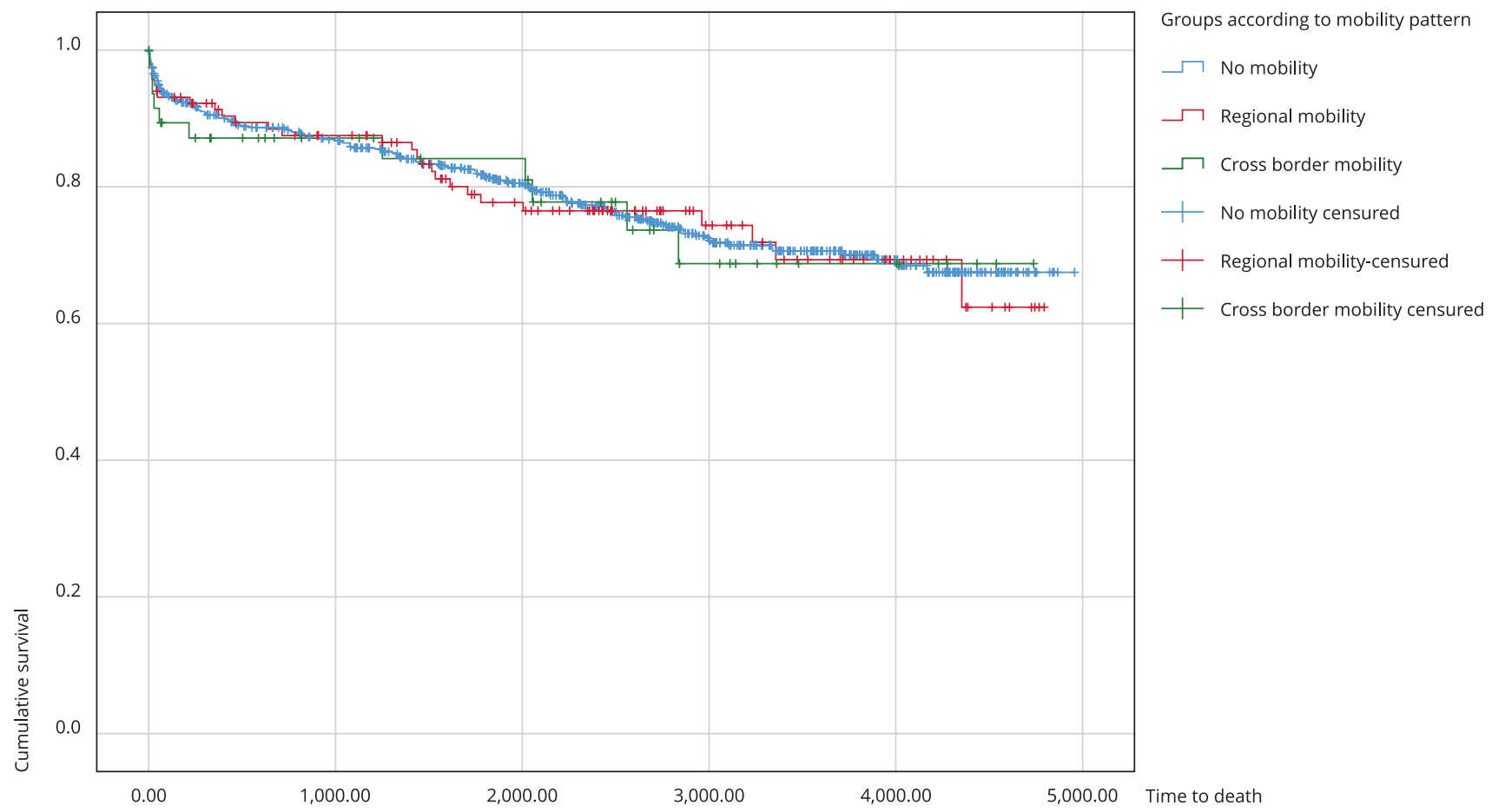

Note: Kaplan-Meier analysis. 
when adjusted for prognostic factors already recognized in the literature (initial CD4 count, CD4 curve, initial viral load, initial hemoglobin, use of HAART, prophylaxis against opportunistic infections, age at the beginning of follow-up, educational level and family income) (Table 2).

Table 2

Cox proportional hazards model with brute and adjusted hazard ratio (HR) for sociodemographic and clinical variables.

\begin{tabular}{|c|c|c|}
\hline Model & $\begin{array}{c}\text { Death } \\
\text { HR }(95 \% \mathrm{Cl})\end{array}$ & p-value \\
\hline \multicolumn{3}{|l|}{ Brute } \\
\hline No mobility & 1.00 & \\
\hline Regional mobility & $1.03(0.69-1.54)$ & 0.891 \\
\hline International mobility & $1.07(0.58-1.97)$ & 0.834 \\
\hline \multicolumn{3}{|l|}{ Adjusted } \\
\hline \multicolumn{3}{|l|}{ Initial CD4 } \\
\hline No mobility & 1.00 & \\
\hline Regional mobility & $0.93(0.60-1.45)$ & 0.755 \\
\hline International mobility & $0.88(0.43-1.81)$ & 0.741 \\
\hline \multicolumn{3}{|l|}{ CD4 curve } \\
\hline No mobility & 1.00 & \\
\hline Regional mobility & $0.98(0.53-1.80)$ & 0.945 \\
\hline International mobility & $0.77(0.28-2.10)$ & 0.609 \\
\hline \multicolumn{3}{|l|}{ Initial viral load } \\
\hline No mobility & 1.00 & \\
\hline Regional mobility & $1.04(0.66-1.64)$ & 0.852 \\
\hline International mobility & $0.94(0.43-2.03)$ & 0.876 \\
\hline \multicolumn{3}{|l|}{ Initial haemoglobin } \\
\hline No mobility & 1.00 & \\
\hline Regional mobility & $1.10(0.72-1.69)$ & 0.634 \\
\hline International mobility & $1.06(0.52-2.17)$ & 0.866 \\
\hline \multicolumn{3}{|l|}{ HAART use } \\
\hline No mobility & 1.00 & \\
\hline Regional mobility & $1.04(0.69-1.55)$ & 0.858 \\
\hline International mobility & $1.13(0.61-2.09)$ & 0.688 \\
\hline \multicolumn{3}{|c|}{ Prophylaxis against opportunistic infections } \\
\hline No mobility & 1.00 & \\
\hline Regional mobility & $1.00(0.67-1.50)$ & 0.982 \\
\hline International mobility & $1.09(0.59-2.02)$ & 0.771 \\
\hline \multicolumn{3}{|l|}{ Age at initial consultation } \\
\hline No mobility & 1.00 & \\
\hline Regional mobility & $1.06(0.71-1.59)$ & 0.761 \\
\hline International mobility & $1.16(0.62-2.14)$ & 0.636 \\
\hline \multicolumn{3}{|l|}{ Educational level } \\
\hline No mobility & 1.00 & \\
\hline Regional mobility & $1.03(068-1.55)$ & 0.888 \\
\hline International mobility & $1.17(0.61-2.23)$ & 0.623 \\
\hline \multicolumn{3}{|l|}{ Family income } \\
\hline No mobility & 1.00 & \\
\hline Regional mobility & $0.97(0.57-1.66)$ & 0.914 \\
\hline International mobility & $1.21(0.53-2.77)$ & 0.654 \\
\hline
\end{tabular}

95\%Cl: 95\% confidence interval; HAART: highly active antiretroviral theraphy. 


\section{Discussion}

In this retrospective cohort study, the exposure to migration, both regional and international, did not show significant association with the risk of death by any cause in both crude and adjusted analyses (adjusted for already known prognostic factors: initial CD4 count, CD4 curve, initial viral load, initial hemoglobin, use of HAART, prophylaxis against opportunistic infections, age at the beginning of follow-up, educational level and family income).

All the three groups had sociodemographic, clinical or laboratorial characteristics related to a better and worst prognosis. Patients living in Paraguay had the highest educational level, family income and frequency of initial viral load $\leq 400$ copies $/ \mu \mathrm{L}$, all of which are related to a better prognosis. However, this group had the smallest proportion of married individuals and patients with initial CD4 count $\geq 500$ cells $/ \mu \mathrm{L}$ and the highest proportion of men, all of which related with a worst prognosis. The cross-border group had a greater number of characteristics related to a better prognosis which can counterbalance the possible negative effect of this international mobility. Patients living in other Brazilian cities of the health department had the highest proportion of female patients and initial CD4 count $\geq 500$ cells $/ \mu \mathrm{L}$, initial hemoglobin $\geq 12 \mathrm{mg} / \mathrm{dL}$, all of which related to a better prognosis. However, this group had the smallest proportion of high income patients, which is related to a worst prognosis. In turn, patients of the reference group had the highest proportion of married patients and use of antiretroviral therapy, all of which are related to a better prognosis. However, this group had the smallest proportion of patients with initial viral load of $\leq 400$ copies $/ \mu \mathrm{L}$ and hemoglobin $\geq 12 \mathrm{mg} /$ $\mathrm{dL}$, which are related to a worst prognosis. We were not able to measure in this research if the most frequent use of antiretroviral therapy by the reference group and the less frequent use of antibiotic prophylaxis among international migrants are related to clinical indication (which could suggest a different rate of clinical progression among groups) or to a lack of access to medication linked to the status of migrant. In summary, all groups had characteristics that pointed to both prognostic directions. Even considering the adjustment, we did not find difference statistically significant among the groups. Other variables that we did not use for adjustment is a possible reason for this finding. This hypothetical other variable probably has not yet been identified in the theoretical framework considering the huge lack of researches about the prognostic impact of cross-border healthcare.

This study is, in the best of our knowledge, the first attempt to evaluate the relationship between a primary outcome with cross-border healthcare with pendulum migration as the mobility pattern and, specifically, the prognostic value of regional and international mobility of HIV patients in search for medical care. Mello et al. 40 found no difference in the quality of prenatal care between Brazilian pregnant women living in Brazil and those living in Paraguay who know the right to receive care in the Brazilian health system. It is likely that, if the acknowledgment of the right of care is similar, the exposure to cross-border healthcare will not be related to different birth outcomes. A similar situation with our study was found by Donnan et al. 44, whose research reported 127 cases of tuberculosis in children between 2005 and 2014 in Queensland, Australia, and, among these cases, 12.6\% were cross-border children who lived in Papua New Guinea and were diagnosed and treated in Australia. There was a statistically significant difference in the rate of successful outcome (completion of treatment) between the groups, with 100\% of cure among Australian children, $97.2 \%$ among temporary and permanent overseas-born patients, and $76.6 \%$ among cross-border patients $(\mathrm{p}<0.005)$. Four of the five deaths registered in the period occurred among cross-border children. The reasons for this difference were increased morbidity in the diagnosis, higher prevalence of drug-resistance, challenges in monitoring the treatment (directed observed treatment), and difficulty to attend scheduled consultations due to logistical problems of transportation 44.

Finally, in border areas of countries with high socioeconomic disparities, it is necessary to discuss and to implement local policies to reduce the lack of access and discrepancy in healthcare quality 45 . We believe that this research, instead of closing research questions and pointing to a more definitive answer, contributes to open the research field about health impact of cross border healthcare for patients and services. 


\section{Contributors}

R. Zaslavsky, B. N. G. Goulart and P. K. Ziegelmann contributed in the study design, data analysis and interpretation; writing the article and critically reviewing the intellectual content; final approval of the version to be published and reesponsible for all aspects of the work in guaranteeing the accuracy and completeness of any part of the work.

\section{Additional informations}

ORCID: Ricardo Zaslavsky (0000-0002-61754573); Barbara Niegia Garcia de Goulart (00000002-2502-5883); Patricia Klarmann Ziegelmann (0000-0002-2851-2011).

\section{References}

1. Allen W. "I am from Busia!": everyday trading and health service provision at the KenyaUganda border as place-making activities. Journal of Borderlands Studies 2013; 28:291306.

2. Guendelman S, Jasis M. Giving birth across the border: the San Diego-Tijuana connection. Soc Sci Med 1992; 34:419-25.

3. Kangas B. Hope from abroad in the international medical travel of Yemeni patients. Anthropol Med 2007; 14:293-305.

4. Andritsos DA, Tang CS. The impact of crossborder patient movement on the delivery of healthcare. International Journal of Production Economics 2013; 145:802-12.

5. Mainil T, Van Loon F, Dinnie K, Botterill D, Platenkamp V, Meulemans $\mathrm{H}$. Transnational health care: from a global terminology towards transnational health region development. Health Policy 2012; 108:37-44.

6. Lunt N, Carrera P. Medical tourism: assessing the evidence on treatment abroad. Maturitas 2010; 66:27-32.

7. Durham J, Blondell SJ. A realist synthesis of cross-border patient movement from low and middle income countries to similar higher income countries. Global Health 2017; 13:68.

8. Breslau J, Borges G, Tancredi D, Saito N, Kravitz R, Hinton L, et al. Migration from Mexico to United States and subsequent risk for depression and anxiety disorders: a cross national study. Arch Gen Psychiatry 2011; 68:428-33.

9. Martinez-Donate AP, Zhang X, Rangel MG, Hovell M, Simon NJ, Amuedo-Dorantes C, et al. Healthcare access among circular and undocumented Mexican migrants: results from a pilot survey on the Mexico-US border. Int J Migr Bord Stud 2014; 1:57-108.

10. Palk L, Blower S. Mobility and circular migration in Lesotho: implications for transmission, treatment and control of a severe HIV epidemic. J Acquir Immune Defic Syndr 2015; 68:604-8.

\section{Acknowledgments}

Team of the Specialized Assistance Service (SAE) of Foz do Iguaçu for permiting us to carry out the research in its facilities. Medical students from the Federal University of Latin American Integration (UNILA) Beatriz Larentis, Eduardo Cordeiro, Gabriel Tomazini, Gabriele dos Santos, João Paulo da Costa Braga, Maria Julia Piai, Patrick Kobayashi Rodrigues, Roberta Serafini, and Vinicius Giesel Hollas for their performance in the data collection.

11. Zaslavsky R, Goulart BNG. Pendulum migration and healthcare in border area. Ciênc Saúde Colet 2017; 22:3981-6.

12. Cintra APU, Delgado PR, Moura R. Movimentos pendulares no Paraná. Caderno IPARDES 2012; 2:15-31.

13. Organization for Economic Co-operation and Development. Redefining territories: functional regions. https://www.oecd-ilibrary.org/ urban-rural-and-regional-development/rede fining-territories_9789264196179-en (accessed on $28 / \mathrm{Jan} / 2017$ ).

14. Jardim ML, Barcellos TM. Mobilidade populacional na região metropolitana de Porto Alegre nos anos 90. São Paulo Perspect 2005; 19:78-95.

15. Aranha V. Mobilidade pendular na metrópole paulista. São Paulo Perspect 2005; 19:96-109.

16. Stamm C, Staduto JAR. Movimentos pendulares das cidades interioranas de porte médio de Cascavel e Toledo, no Paraná. Rev Bras Estud Popul 2008; 25:131-49.

17. Brasil. Lei no 8.080 , de 19 de setembro de 1990. Dispõe sobre as condições para a promoção, proteção e recuperação da saúde, a organização e o funcionamento dos serviços correspondentes e dá outras providências. Diário Oficial da União 1990; 20 set.

18. Giovanella L, Guimarães L, Nogueira VMR, Lobato LV, Damascena GN. Saúde nas fronteiras: acesso e demandas de estrangeiros e brasileiros não residentes ao SUS nas cidades de fronteira com países do MERCOSUL na perspectiva dos secretários municipais de saúde. Cad Saúde Pública 2007; 23 Suppl 2:S251-66.

19. Cazola LHO, Pícoli RP, Tamaki EM, Pontes ERJC, Ajalla ME. Atendimentos a brasileiros residentes na fronteira Brasil-Paraguai pelo Sistema Único de Saúde. Rev Panam Salud Pública 2011; 29:185-90.

20. Instituto Brasileiro de Geografia e Estatística. Foz do Iguaçu. https://cidades.ibge.gov.br/bra $\mathrm{sil} / \mathrm{pr} /$ foz-do-iguacu/panorama (accessed on 05/Feb/2017). 
21. Instituto Provincial de Estadística y Censos de Misiones. Población por sexo según município. https://ipecmisiones.org/wpcontent/uploads/2019/04/IPEC-Misiones1-Poblaci\%C3\%B3n-por-sexo-seg\%C3\%BAnmunicipio-Censo-2010.pdf (accessed on 05/ Feb/2017).

22. Secretaria Técnica de Planificación del Desarrollo Econômico y Social. Paraguay: proyección de población por sexo y edad, según distrito, 2000-2025 - revisión 2015. Fernando de la Mora: Dirección General de Estadística, Encuestos y Censos; 2015.

23. Dirección General de Estadística, Encuestas y Censos. Inmigrantes em admisión permanen te por año y sexo, según país de origen (20102012). https://www.dgeec.gov.py/Publicacio nes/Biblioteca/anuario2012/anuario\%202012. pdf (accessed on 07/Feb/2017).

24. Ministério das Relações Exteriores. Brasileiros no mundo: estimativas populacionais das comunidades. http://www.brasileirosnomun do.itamaraty.gov.br/a-comunidade/estimativas -populacionais-das-comunidades (accessed on 07/Feb/2017)

25. Secretaria de Vigilância em Saúde, Ministério da Saúde. Boletim epidemiológico HIV/AIDS 2016; ano V, n. 01.

26. The Joint United Nations Programme on HIV/ AIDS. Paraguay. https://www.unaids.org/en/ regionscountries/countries/paraguay (accessed on 30/Mar/2018).

27. Alum JNM, Bejarano MSC. Sistema de salud de Paraguay. Rev Salud Pública Parag 2011; 1:13-25.

28. Hogg RS, Strathdee SA, Craib KJP, O'Shaughnessy MV, Montaner JSG, Schechter MT. Lower socioeconomic status and shorter survival following HIV infection. Lancet 1994; 344:1120-4.

29. Kposowa AJ. Marital status and HIV/AIDS mortality: evidence from the US National Longitudinal Mortality Study. Int J Infect Dis 2013; 17:e868-74.

30. Silveira MPT, Maurer P, Guttier MC, Moreira LBM. Factors associated with therapeutic success in HIV-positive individuals in Southern. J Clin Pharm Ther 2015; 40:192-5.

31. Sobrino-Vegas P, Rodríguez-Urrego J, Berenguer J, Caro-Murillo AM, Blanco JR, Viciana $\mathrm{P}$, et al. Educational gradient in HIV diagnosis delay, mortality, antiretroviral treatment initiation and response in a country with universal health care. Antivir Ther 2012; 17:1-8.

32. McManus H, O'Connor CC, Boyd M, Broom J, Russell D, Watson K, et al. Long term survival in HIV positive patients with up to 15 years of antiretroviral therapy. PLoS One 2012; 7:e48839.

33. Ledergerber B, Egger M, Opravil M, Telenti A, Hirschel B, Battegay M, et al. Clinical progression and virological failure on highly active antiretroviral therapy: a prospective cohort study. Lancet 1999; 353:863-8.
34. Harris RJ, Sterne JA, Abgrall S, Dabis F, Reiss P, Saag M, et al. Prognostic importance of anaemia in HIV type-1-infected patients starting antiretroviral therapy: collaborative analysis of prospective cohort studies. Antivir Ther 2008; 13:959-67.

35. Djawe K, Buchacz K, Hsu L, Chen MJ, Selik RM, Rose C, et al. Mortality risk after AIDSdefining opportunistic illness among HIV-infected persons - San Francisco, 1981-2012. J Infect Dis 2015; 212:1366-75.

36. Huang P, Tan J, Ma W, Zheng H, Lu Y, Wang N, et al. Outcomes of antiretroviral treatment in HIV-infected adults: a dynamic and observational cohort study in Shenzen, China, 20032014. BMJ Open 2015; 5:e007508.

37. Hoffmann CJ, Fielding KL, Charalambous S, Innes $\mathrm{C}$, Chaisson RE, Grant AD, et al. Reducing mortality with cotrimoxazole preventive therapy at initiation of antiretroviral therapy in South Africa. AIDS 2010; 24:1709-16.

38. Taylor BS, Reyes E, Levine EA, Khan SZ, Garduño S, Donastorg Y, et al. Patterns of geographic mobility predicts barrier to engagement in HIV care and antiretroviral treatment adherence. AIDS Patient Care STDS 2014; 28:284-95

39. Bilinski A, Birru E, Pecharsky M, Herce M, Kalanga N, Neumann C, et al. Distance to care, enrollment and loss to follow-up of HIV patients during decentralization of antiretroviral therapy in Neno district, Malawi: a retrospective cohort study. PLoS One 2017; 12:1-13.

40. Mello F, Victora CG, Gonçalves H. Health at the border: quantitative and qualitative analysis of patients treated at the maternal and child center in Foz do Iguaçu, Brazil. Ciênc Saúde Colet 2015; 20:2135-45.

41. Mocroft A, Ledergerber B, Zilmer K, Kirk O, Hirschel B, Viard JP, et al. Short-term clinical disease progression in HIV-1-positive patients taking combination antirretroviral therapy: the EuroSIDA risk-core. AIDS 2007; 21:1867-75.

42. Egger M, May M, Chêne G, Phillips NA, Ledergerber B, Dabis F, et al. Prognosis of HIVinfected patients starting highly active antiretroviral therapy: a collaborative analysis of prospective studies. Lancet 2002; 360:119-29.

43. Departamento de DST e AIDS, Secretaria de Vigilância em Saúde, Ministério da Saúde. Nota técnica no 208/2009. Descrição: orientações para abordagem consentida, alerta de má adesão aos antirretrovirais e critério de abandono ao tratamento. http://www.aids.gov.br/pt-br/ legislacao/nota-tecnica-no-2082009 (accessed on 30/Mar/2018).

44. Donnan EJ, Coulter C, Simpson G, Clark J, Nourse C. Paediatric tuberculosis in Queensland, Australia: overrepresentation of cross-border and indigenous children. Int J Tuberc Lung Dis 2017; 21:263-9.

45. Bühring MA. Mobilidade humana (migrantes/ deslocados/refugiados) cidadania no contexto global-local. In: Bühring MA, editor. Mobilidade, fronteiras e direito à saúde. Porto Alegre: Livraria do Advogado; 2016. p. 15-81. 


\section{Resumo}

$O$ ato de atravessar uma fronteira internacional para receber cuidados de saúde é uma realidade nas áreas fronteiriças. O fluxo tende a ser em direção à cidade com os melhores recursos humanos e melhor infraestrutura em saúde. Embora sejam conhecidos os fatores prognósticos relacionados à infecção pelo HIV, o valor prognóstico desse tipo de migração a longo prazo tem recebido menos atenção. Este estudo divide e compara o prognóstico em três grupos de pacientes com HIV: um envolvido em mobilidade regional, outro em mobilidade transfronteira em busca de assistência e o terceiro constituído de pacientes que residem na mesma cidade onde o serviço de saúde está localizado. Este estudo de coorte retrospectiva utiliza dados de prontuários de um serviço de saúde no Brasil. Ao analisar a sobrevida com o teste de log-rank e modelos riscos proporcionais de Cox, a sobrevida geral não mostrou diferença significativa entre pacientes que recebiam cuidados através da mobilidade regional $(H R=1,03$; IC95\%: 0,69-1,54; $p=0,89)$ ou transfronteira $(H R=1,07$; IC95\%: 0,58-1,97; $p=0,83)$ e aqueles que recebiam atendimento na cidade onde residiam. Essa falta de diferença se manteve quando a análise foi ajustada para os fatores prognósticos conhecidos. Neste estudo de coorte retrospectiva, a exposição à migração regional ou internacional não mostrou associação significativa com o risco de óbito por qualquer causa, de acordo com a análise bruta e as análises ajustadas para os fatores prognósticos já conhecidos. Este foi o primeiro estudo a considerar o papel prognóstico da assistência transfronteira para pacientes com HIV. Apesar desses achados, enfatiza-se a necessidade de monitorar o grau e as características clínicas e demográficas da demanda por assistência com origem do lado oposto da fronteira, além de utilizar esses dados no processo decisório na gestão da saúde.

HIV; Prognóstico; Áreas de Fronteiras; Saúde nas Fronteiras

\section{Resumen}

El hecho de cruzar una frontera internacional en búsqueda de asistencia sanitaria es una realidad en las áreas fronterizas y el flujo migratorio se dirige hacia la ciudad con más recursos humanos y sanitarios. A pesar de que se conocen los diferentes factores pronósticos relacionados con el VIH, el valor pronóstico de este tipo de movilidad continúa todavía olvidado durante mucho tiempo. Este estudio compara los pronósticos de pacientes de VIH de tres grupos, uno implicado en la movilidad regional, otro en la movilidad fronteriza en búsqueda de asistencia sanitaria y el grupo de referencia que estaba compuesto por pacientes viviendo en la misma ciudad donde se encontraban los servicios sanitarios. Este es un estudio retrospectivo de cohorte, usando expedientes médicos de un servicio de salud en Brasil. En los siguientes análisis de supervivencia con prueba log-rank y modelos de Cox de riesgo proporcional, en cuanto a la supervivencia general no hubo una diferencia significativa entre pacientes que estaban implicados en la movilidad regional $(H R=1,03 ; 95 \% C I$ : 0,69-1,54; $p=0,89)$ o internacional $(H R=1,07$; 95\%CI: 0,58-1,97; $p=0$,83) y aquellos que no lo estuvieron. Esta falta de diferencia se mantuvo cuando se ajustó para los factores pronósticos conocidos. En este estudio retrospectivo de cohorte, la exposición tanto a la migración regional como la internacional no tuvo una asociación significativa con el riesgo de muerte por alguna causa en los análisis crudos o ajustados para los factores pronósticos ya conocidos. Se trata del primer estudio en considerar el papel pronóstico de la asistencia sanitaria transfronteriza en pacientes con VIH. A pesar de estos resultados, existe la necesidad de un monitoreo sobre la extensión y las características clínicas y demográficas de la demanda de servicios sanitarios al otro lado de la frontera, así como el énfasis del uso de estos datos para la toma de decisiones en la gestión de salud.

VIH; Pronóstico; Áreas Fronterizas; Salud

Fronterizas
Submitted on $23 / \mathrm{Sep} / 2018$

Final version resubmitted on 20/Dec/2018

Approved on 29/Mar/2019 